\title{
Clark Level II
}

National Cancer Institute

\section{Source}

National Cancer Institute. Clark LevelII. NCI Thesaurus. Code C94813.

A morphologic finding indicating that the cutaneous melanoma has invaded part of the papillary dermis but the malignant cellular infiltrate has not reached the papillary-reticular dermis interface. 